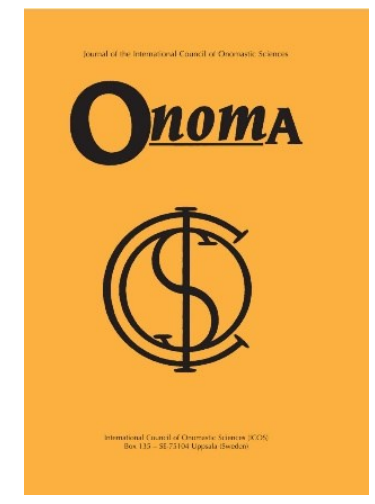

\title{
Onoma 50
}

Journal of the International Council of Onomastic Sciences

ISSN: 0078-463X; e-ISSN: 1783-1644

Journal homepage: https://onomajournal.org/

\section{Names and magic: \\ Onomancy in Suzette Haden Elgin's Ozark trilogy}

DOI: 10.34158/ONOMA.50/2015/4

\section{Donna L. Lillian}

Department of English

Appalachian State University

Boone, NC, 28608, USA

lilliandl@appstate.edu

To cite this article: Lillian, Donna L. 2015. Names and magic: Onomancy in Suzette Haden Elgin's Ozark trilogy. Onoma 50, 103-119. DOI: 10.34158/ONOMA.50/2015/4

To link to this article: https://doi.org/10.34158/ONOMA.50/2015/4

(C) Onoma and the author.

\section{Names and magic: Onomancy in Suzette Haden Elgin's Ozark trilogy}

Abstract: Suzette Haden Elgin's Ozark trilogy is set in the 31st century on a fictional planet settled in the year 2021 by humans from the Ozark Mountains of Earth. The inhabitants of planet Ozark utilize magic, the most important aspect of which is the Proper Naming system by which Grannys name every girl-baby. Elgin's Proper Naming system closely resembles contemporary Western numerology, in which letters are assigned numerical equivalences and significance can be assigned the name based on its number. In the novels, a great deal of attention is paid to names and naming; however, Elgin's system is incomplete and it contains inconsistencies that ultimately detract from the overall elegance of the system.

Keywords: Onomancy, numerology, Ozark, proper naming, Suzette Haden Elgin. 


\section{Noms et magie : Numérologie dans la trilogie d'Ozark de Suzette Haden Elgin}

Résumé : La Trilogie d'Ozark [Ozark Trilogy] de Suzette Haden Elgin se déroule au XXXI siècle sur une planète fictive colonisée en l'an 2021 par des êtres humains qui habitaient auparavant les montagnes d'Ozark sur la Terre. Les habitants de la planète Ozark ont recours à la magie qui repose en grande partie sur un système d'attribution de noms propres par lequel des Grannys nomment chaque bébé fille. Le système de nomination créé par Elgin ressemble étroitement à la numérologie occidentale, où l'on attribue à des lettres des équivalences numériques, et une signification peut être associée à un nom en fonction d'un nombre. Dans ses romans, elle accorde aux noms et à la nomination une grande attention; cependant, le système d'Elgin est incomplet et présente des incohérences qui, en fin de compte, portent atteinte à l'élégance globale du système.

Mots-clés : La numérologie, Ozark, magie, Suzette Haden Elgin.

\section{Namen und Zauberei:}

\section{Das Numerologiesystem der Ozark Trilogie von Suzette Haden Elgin}

Zusammenfassung: Die Ozark Trilogie von Suzette Haden Elgin findet im 31. Jahrhundert auf einem erfundenen Planeten Ozark statt. Dieser Planet wurde im Jahr 2021 von Menschen des Planeten Erde besiedelt; genauer, diese Menschen stammten aus den Ozark Bergen der Erde. Die Einwohner des Ozark Planeten benutzen Zauberei, dessen wichtigster Bestandteil ein Eigennamengebungssystem ist. Grossmütter (Grannies) benutzen dieses System, in dem sie jedem weiblichen Baby einen Namen geben. Elgins Eigennamensystem gleicht dem gegenwärtigen westlichen Numerologiesystem, in dem Buchstaben Zahlen gleichgesetzt werden und Namen auf dem jeweiligem Zahlenwert basierende Bedeutung zugeteilt wird. In diesen Romanen wird den Namen und der Namengebung große Aufmerksamkeit geschenkt, Elgins System jedoch ist unvollständig und enthält Widersprüche, die letzten Endes die Anmut und Eleganz des Systems beeinträchtigen.

Schlüsselbegriffe: Numerologiesystem, Ozark, Eigennamenbungssystem, Suzette Haden Elgin. 


\title{
Names and magic: Onomancy in Suzette Haden Elgin's Ozark trilogy
}

\author{
DONNA L. LILLIAN
}

\section{Introduction}

"Magic is a universal aspect of human consciousness; it is inherent in the mind" (Greenwood 2009: 4). Yet if that is so, there is little agreement about the nature of magic. For some believers, magic is the antithesis of the faith system that they uphold. Conversely, for others, magic is at the very heart of their religion. Science seeks to catalogue, define, and explain what is real, and magic is dismissed by Western science as, at best, irrelevant and at worst, nonexistent. "In Western rationalist cultural history magic has been systematically marginalized. Magic has been seen to be trying to do what science does, but is failing because it is based on false premises" (Greenwood 2009: 4-5). Yet in fiction, and particularly in science fiction, all things are possible, and in The Ozark trilogy, Suzette Haden Elgin plays with the genre of science fiction, adding magic as a foundational principle in the cosmology of a society that is scientifically advanced enough to build a spacecraft and travel nine years to settle on a new planet. Magic on this fictional planet named Ozark replaces neither science nor religion but functions alongside both.

P.W.F. Brown asserts that "[t]he magic spell surrounding names is very strong and difficult to break" (1954: 27), and that is true on Ozark, where onomancy functions in a very particular manner. Onomancy, defined as "divination from a name or names, esp. the letters of a personal name" (OED online, s.v. onomancy), can take various forms. For example, one system of onomancy is based on Futhark, the ancient Germanic runic alphabet. The word futhark is simply an acronym based on the first 6 runes in the alphabet. Futhark is not a numerology-based system; rather, in Futhark name interpretation, each rune has a meaning and the meaning of a name is discerned by considering the combined force of all the runes that make up the name. For magical purposes, the runes are grouped into three aettir, each associated with a Norse god (Nomenology 1999: 27). The process of discerning the meaning of a name in Futhark involves first transposing the English spelling into runes, then looking over the pattern to see whether there is a strong influence from one or more of the aettir. After that, practitioners are directed to "use the meanings and 
interpretations $[\ldots]$ to work through each letter to get a broad sense of all the different influences that play upon your life" (Nomenology 1999: 27).

A second major system of onomancy is Kabbalah, a mystical philosophy of the Jewish religion originating in 12th century Europe. In Kabbalah, it is believed that "an analysis of your name based on the numerical values of the letters composing that name will yield significant insight into your personality and deeper spiritual traits" (Nomenology 1999: 15). Kabbalah employs the ancient Hebrew system of letter-number analysis known as gematria, "a cabbalistic method of interpreting the Hebrew Scriptures by interchanging words whose letters have the same numerical value when added" (OED online, s.v. gematria). Since gematria is based on the Hebrew alphabet, using gematria to interpret non-Hebrew names requires some adaptation of the system. The Hebrew alphabet contains 22 letters, all of them consonants, whereas the English alphabet, for example, contains 26 letters including both consonants and vowels, and the inconsistency of sound-spelling relationships in English make application of Kabbalah to English names particularly problematic.

A third system of onomancy, known as Western numerology or just as numerology, is closest to the system Elgin uses in her Ozark novels. "Western numerology developed primarily from the Hebrew methods of gematria and the Pythagorean techniques of analysing the meanings of individual numbers" (Nomenology 1999: 33). The Oxford English dictionary online (OED online) defines numerology as "Divination by numbers; the study of the occult or hidden meanings of numbers". While such a system of numerology could potentially explore the significance of numbers in any aspect of human existence, it is the application of numerology to personal names that is of relevance to the present discussion, and both Elgin's system and "standard" Western numerology will be explored below, following an overview of The Ozark trilogy itself.

\section{The Ozark trilogy}

The Ozark trilogy was originally published in 1981 as three separate books, Twelve fair kingdoms (1981a), The grand jubilee (1981b), and And then there'll be fireworks (1981c), and it was then republished in 2000 in a single volume. The author, Suzette Haden Elgin (1936-2015) was an American linguist, poet, and author. Her non-fiction writing includes, among other things, the Gentle art of verbal self-defense series, consisting of twenty-three books, the first of which was published in 1980. The general public may know her best for this verbal selfdefence series, but the science fiction community knows her best for her Native tongue trilogy, consisting of Native tongue (1984), The Judas rose (1987), and Earth song (1993). Elgin's Ozark trilogy has tended to receive less attention than 
her other works, but it is, nevertheless, well known to her science fiction fan base, and it is the focus of the present study.

The fictional premise of the Ozark trilogy is that in the year 2012, a group of twelve families from the Ozark Mountains in the USA secretly build a spacecraft and leave Earth, in search of a new planet similar to Earth but free of the pollution and violence that had driven them to leave their home planet. They travel for nine years, and then, running out of both food and fuel, they finally land on a planet which they name Ozark (Elgin 2000: 495-496). The narration is set a thousand years after the settlers first land on the planet. The original Ozarkers had already used some magic when they lived on Earth, but planet Ozark operates on a magic of its own, and the new Ozark society evolves to become completely dependent upon magic, which Ozarkers divide into five levels:

Common Sense level, available to everyone unless they just plain weren't interested, same as the times tables and the alphabet were. Middle Level, for the ambitious, or those as didn't care to be overdependent on the Grannys. Granny Magic, for the Grannys only; Hifalutin magic, for the Magicians. And for the Magicians of Rank, the highest level - the Formalisms \& Transformations. (Elgin 2000: 285)

Granny magic includes basic healing, general household spells, and the administration of minor punishments, all of which could also be done by Magicians and Magicians of Rank, except that they consider it beneath them. There is, however, one magic that is unique to Grannys: Proper Naming.

\section{Naming in the Ozark trilogy}

On planet Ozark, boys are named by their parents in a pattern that tends to recycle a small set of names over and over, and there is no magical significance to males' names. The main criterion seems to be that their names should be euphonious, unlike the name James John Guthrie, which is described as "three rocks landing on a pavement, and the third one bouncing" (Elgin 2000: 62). There are twelve surnames on Ozark, based on the original twelve families who settled there: Airy, Brightwater, Clark, Farson, Guthrie, Lewis, McDaniels, Motley, Purdy, Smith, Traveller, and Wommack. Surnames are patrilineal, and women continue to be identified by the family name of their father, even after they marry. Examples of male names are Jacob Donahue Wommack the 24th, Michael Stepforth Guthrie the 11th, and Donald Patrick Brightwater the 133rd. 
By contrast, girls' names are magically significant and must be bestowed by Grannys according to the principles of Proper Naming, since a girl improperly named could bring bad luck on herself and her family (Elgin 2000: 503). For example, the entire Wommack family is considered cursed because generations earlier, a girl-baby was improperly named (Elgin 2000: 279). Proper Naming involves the use of numerology, and it is the job of the Grannys to discern what number belongs to a girl-baby and to bestow on her a name that corresponds with that number.

When one of our Grannys names a girlbaby Rose, we ask ourselves - what does that mean? We add up the values of those letters, and we look carefully and with respect at their... uh... total, and we ask ourselves - what is their significance? And we don't call that simpleminded, for we know that Naming is serious... that the very... uh, the fabric of our lives depends upon Proper Naming! (Elgin 2000: 257)

Elgin is not explicit about all the details of Proper Naming, but she provides some information, including the number-letter correspondences included in Table 1.

Table 1: Proper Naming number-letter correspondences (Elgin 2000: 504)

\begin{tabular}{|l|l|l|l|l|l|l|l|l|}
\hline $\mathbf{1}$ & $\mathbf{2}$ & $\mathbf{3}$ & $\mathbf{4}$ & $\mathbf{5}$ & $\mathbf{6}$ & $\mathbf{7}$ & $\mathbf{8}$ & $\mathbf{9}$ \\
\hline A & B & C & D & E & F & G & H & I \\
\hline J & K & L & M & N & O & P & Q & R \\
\hline S & T & U & V & W & X & Y & Z & \\
\hline
\end{tabular}

To determine the number that corresponds with a specific name, each letter of the name is assigned a number according to the grid in Table 1, then the numbers are added together. If the total comes to a single-digit number, then that is the number-value for that name. The name Sue illustrates such a pattern:

Sue: $\quad 1+3+5=9$

If, however, the sum of the numbers results in a two-digit number, then those digits are added together to produce a single-digit number, as seen with the name Jessica:

Jessica: $\quad 1+5+1+1+9+3+1=21 \rightarrow 2+1=3$ 
Often the sum of digits still results in a two-digit number, so the pattern of adding the digits is repeated until one obtains a number less than or equal to nine. The name Charity illustrates this pattern:

$$
\text { Charity: } \quad 3+8+1+9+9+2+7=39 \rightarrow 3+9=12 \rightarrow 1+2=3
$$

Table 2 lists the female character names in the trilogy according to their corresponding number.

Table 2: Female character names by number

\begin{tabular}{|l|l|l|}
\hline One & Two & Three \\
Crimson & Avalon & Caroline-Anne \\
Jewel & Emmalyn & Charity \\
Troublesome & Gilead & Jessica \\
& Ivy & Thorn \\
& Shandra & \\
Violet & \\
\hline Four & Five & Six \\
Demarest & Becca & Cecelia \\
Joan & Marygold & Chastity \\
Linden & Suzannah & Diamond \\
Mynna & Vine & Dorothy \\
Ruth & & Marycharlotte \\
& & Miranda \\
& & Rosemary \\
Sally \\
\hline Seven & & Nine \\
Amanda & Una \\
Anne & Eight & \\
Naomi & Cristabel & \\
Silverweb & Flag & Responsible \\
\hline
\end{tabular}

\section{Western numerology}

The letter-number correspondences Elgin uses are consistent with what the Nomenology Project (1999) identifies as Western numerology, although her interpretation of those numbers differs from theirs. "Western numerology developed primarily from the Hebrew methods of gematria and the Pythagorean techniques of analyzing the meanings of individual numbers" (Nomenology 1999: 33). The Nomenology Project's detailed description of the meaning of each number from one to nine is condensed and summarized here, and may be taken to represent a mainstream form of numerology (1999: 35-37):

One: the beginning or origin of all things; unity, wholeness, selfsufficiency; masculine energy; aggression (positive or negative); 
often outgoing, aggressive, achievement-oriented; leaders; dynamic, expressive; occasionally obstinate \& overbearing.

Two: duality, polarity, the interaction of opposites; feminine energy; good at reconciling and negotiating between conflicting interests; compromising, passive, follower not leader; creativity.

Three: family \& family values; time (past, present, future); assertive, generally positive; can be blunt.

Four: stability, foundations, solidity, the earth, the four elements; equilibrium \& balance; reliable, stable, efficient, well organized, calm, respectable; can be dull or slow, even boring, if not balanced with creativity.

Five: the material world, humanity, the 5 senses, instability, distraction; uncertainty and chance; activity \& energy; adventurous, willing to try new things; risk taker; resilient.

Six: health, balance and harmony; an androgynous quality; creative, artistically oriented, willing to take action to accomplish goals; can be nit-picky or fastidious.

Seven: spirituality, mysticism, perfection, order, good fortune; artistic, intuitive, empathetic; can be aloof, moody, depressed.

Eight: regeneration, stability, new life, eternity, justice, equilibrium, balance; materialism \& worldly interests; tenacity; can be hardheaded.

Nine: completeness, fulfilment; possibly self-centred and egotistical; can have lofty goals \& high ambition.

\section{Interpreting Elgin's numerology}

Unfortunately, Elgin does not elaborate on the characteristics associated with all of the numbers in the Ozark Proper Naming system, so one is left to infer the characteristics from evidence scattered throughout the novels. What follows is an attempt to recreate Elgin's system from the available evidence in the novels.

One: The reader is given no definition, not even a partial one, for the number one, but some inferences are possible based on particular characters in the story. Crimson of Airy, for example, is described in this way: "She was a one, and she had everything that went with being a one, and of the five women to become Magicians on Ozark in the thousand years since First Landing, only Crimson of Airy had made any mark. If it hadn't been forbidden, she'd have been a Magician of Rank herself, no question" (Elgin 2000: 60). Since Crimson is no longer alive at the time of the narrative, we do not meet her, and all we know of her character is what Responsible reveals in that quotation. Jewel of 
Wommack is another example of a one. When the magic of the planet is suspended and when their technology fails, Jewel takes charge in her kingdom and establishes a strict but effective Teaching Order, sacrificing her own dreams of marriage and motherhood for the good of her community (Elgin 2000: 477-481). Yet as a twelve-year-old she had been feisty and had earned the nickname Little Wickedness from her brother (Elgin 2000: 176).

The most important character bearing the number one is Troublesome of Brightwater, sister of Responsible, the protagonist of the story. Troublesome is a more complex and nuanced character than her name suggests, but in a society in which one's name encapsulates one's destiny, she embraces hers, annoying the people around her until she reaches an age when she can leave the family and move to a mountaintop to live undisturbed, away from other people. However, when her sister Responsible is incapacitated and the Ozarkers are under threat of annihilation, it is to Troublesome that the Grannys turn for help, and it is she, along with Silverweb of McDaniels, who save Responsible, and by extension save the planet. Based on the characters of Crimson, Jewel, and Troublesome, one can infer that a one is independent of spirit, highly capable, unconventional, and willing to sacrifice the comfortable roles of traditional women in their society. Yet none of this explains why Responsible thinks to herself about a stranger that "she could be a one like Crimson of Airy and a threat to my life and the Kingdom of Brightwater" (Elgin 2000: 69). There is no other evidence that a one is likely to be dangerous to her.

Comparing Elgin's 'one' characters with the description of a one in Western Numerology, there is a reasonable degree of consistency. Crimson, Jewel, and Troublesome are self-sufficient and achievement-oriented, at least some of the time. Jewel assumes a leadership role as the founder and head of the Teacher Order and Crimson is a leader of sorts as a Magician. Troublesome is a reluctant leader, but she takes charge when it is absolutely necessary to do so. Perhaps the numerological features of being obstinate and overbearing are those which fit Troublesome the best, or at least fit the public face she is forced by her name to assume. Even if the ones do not all display all of the characteristics listed for ones, the major one characters do not blatantly contradict those features.

Two: About the number two Elgin explains, "A female whose name came to the number two was intended by destiny to be passive and submissive and weak" (Elgin 2000: 381). This explanation was provided in the context of punishment being meted out against a very young Avalon of Wommack, who was rebelling against an arranged marriage. Her resistance to the marriage was compounded, according to Granny Leeward, by the fact that being rebellious constituted a sin against her naming. By contrast, Ivy of Wommack, a very meek serving maid at Castle Motley, is an example of a two who lived up to 
her number (Elgin 2000: 86-87). Similarly, Violet of Smith, a serving maid at Castle Wommack (Elgin 2000: 120-124), Shandra of Clark, a serving maid at Castle Brightwater (Elgin 2000: 286), and Emmalyn of Clark, "poor puny thing" and wife of Jubal Brooks Brightwater the 11th (Elgin 2000: 6) provide examples of typical twos. A problem arises, however, with Gilead of Wommack, a dutiful and capable daughter whose name is definitely a two $(7+9+3+5+1+4=29 \rightarrow 2+9 \rightarrow 11 \rightarrow 1+1 \rightarrow 2)$ but who is misidentified as a six in the novel (Elgin 2000: 351). The problem of Gilead will be taken up below, but notwithstanding that seeming contradiction, Elgin seems to have achieved a degree of consistency between the number two and the characteristics she attributes to that number. Passivity is also a feature that western numerology associates with the number two, so there is some overlap between Elgin's system and western numerology here. However, the Nomenology Project also suggests that twos are good at reconciling and negotiating between conflicting interests (1999: 35), but there is no evidence of that in Elgin's characters.

Three: The reader learns about three primarily through descriptions of specific characters. Elgin tells the reader this about Charity: "A three she was, and she lived up to the number; in everything that Charity of Guthrie did, she succeeded with a kind of careless ease, as if there was nothing to it at all" (Elgin 2000: 52). And about Jessica she writes, "[Jessica] was in the usual run of things a tower of strength. She was a true Three: brilliant, creative, highspirited, and one for whom everything seemed to come easily. She had slipped into the Teaching Order as a hand slips into a glove made to its measure" (Elgin 2000: 477). Caroline-Anne, twelve-year-old daughter of Charity, is described as being a lot like her mother, and when she is assigned the task of writing a rhyming song to commemorate Responsible's great quest and is given three days to complete it, she returns after just half an hour with a finished 10-verse song (Elgin 2000: 150-154), thereby seeming to live up to the number three with her creativity and "careless ease."

The most prominent three in the story is Thorn of Guthrie, mother of Responsible of Brightwater. Both Responsible and her sister Troublesome have a difficult relationship with their mother, and Responsible describes her mother in rather unflattering terms:

She'd never make a Granny; she was too quick with that tongue and not able to put it under rein when the circumstances called for it, and her age she had no excuse. She'd be a flippant wench at eighty-five, still stuck in her magic at Common Sense level, like a child. Lucky she was beautiful, since men have no more sense than to be distracted by such things, and Thorn was that. (Elgin 2000: 7)

Thorn's apparent lack of general competency, exemplified by the fact that she regularly forgets her daughter's birthday (Elgin 2000: 282), seems to 
contradict the high aptitude associated with the number three. Nevertheless, three does seem to be associated with someone bright, spirited, strong, and talented, even if Thorn's talent seems to be limited to the skill of remaining attractive to men.

Three in Western numerology is typically associated with family and family values, but Elgin's threes are not celebrated for those values. Perhaps a case could be made that Charity, Caroline-Anne, and Jessica at least do not contradict those values, but Thorn of Guthrie is anything but family-oriented. The only feature of a three that she seems to display is bluntness.

Four: Four is apparently an undesirable number, though we never discover why the narrator, Responsible, considers it so. Arriving exhausted at Castle Farson, Responsible is greeted by Marycharlotte and, too tired even to calculate her number, she thinks to herself, "[S]he could be any number she chose, including the horrible four" (Elgin 2000: 69). Marycharlotte is not, of course, a four, but other than that passing thought of Responsible's, we are given no information at all about the number four, and we must infer what we can from characters who bear that number. Ruth of Motley, Responsible's paternal grandmother, is a four, and we see more of her than of any other four in the story. She is quite a capable woman and she sometimes sides with Responsible against her mother, or at least keeps Thorn in check. On one such occasion, Responsible "blessed Ruth of Motley for her solid common sense" (Elgin 2000: 233).

We meet Demarest of Wommack, another four, only briefly as she, a guardmaid at Castle McDaniels, speaks in a saucy manner to Responsible and does her job in a barely competent manner (Elgin 2000: 18). Joan of Lewis, a four, is a wise and very elderly servingmaid at Castle McDaniels, where she was born and where she has served loyally all her life (Elgin 2000: 328-334). Nothing in Joan's speech or demeanour would justify applying the adjective "horrible" to her or to the number four. Linden of Lewis, wife of Whitney Crawford Smith, is described as "undoubtedly the most capable of the women there [at Castle Smith] - which was saying very little" (Elgin 2000: 280), and nothing in her brief appearance in the story would justify the adjective "horrible." The last four in the story is Mynna of McDaniels, a bridgewraith. Twenty years earlier, the 10-year-old Mynna had fallen off the bridge, hit her head, and drowned, and since then she periodically haunts the bridge and cries (Elgin 2000: 265-266). While Mynna is harmless, she comes closest to deserving the adjective "horrible," but none of the other fours manifest any horribleness at all.

With her negative characterization of the "horrible" number four, Elgin seems to directly contradict western numerology, which associates four with calm, balance, equilibrium, respectability, and stability. Ruth of Motley does exemplify those characteristics. Mynna, falling off a bridge, quite literally 
contradicts the idea of balance, and her ghost's demeanour is anything but calm. Thus, we have a contradiction in which at least one character, Ruth, is consistent with the numerological features of a four, yet Elgin's characterization, through the narrator, of four as "horrible" is inconsistent with Western numerology.

Five: Efficiency and discipline are associated with number five, according to this description of Becca of McDaniels: "[...] Becca of McDaniels was a true Five, she'd as soon take your head off as look at you, and she ran the Brightwater kitchen the way her husband ran its stables. No sass, no slack, and no time to breathe from the minute you got there until you were through by the clock" (Elgin 2000: 361). Another five, Vine of Motley is a young mother whose baby is magically kidnapped and held in stasis for more than two months. Apart from being portrayed as a doting mother, Vine is not developed as a character and could have been any number. A third minor character, Suzannah of Farson is married to Jeremiah Thomas Traveller the 26th, head of the stern Traveller family, but we do not learn anything else about her. Finally, Marygold of Purdy, wife of Delldon Mallard Smith, head of Castle Smith, is a five who apparently couldn't even add simple sums (Elgin 2000: 258) and whom Granny Gableframe considers to be as ill-informed as the notoriously stupid family she has married into (Elgin 2000: 275). Thus, Marygold seems to contradict the kind of efficiency and effectiveness exemplified by Becca, the poster-child of fives.

Marygold may fit western numerology's notion of a five better than she fits Elgin's notion. The Nomenology Project refers to instability, distraction, and uncertainty in connection with the number five (1999: 36), and that seems to fit Marygold. Becca's practical efficiency may be consistent with numerology's connection of five with the material world, but in no other respect does she seem to fit with their description of a five. Thus, there is very little connection between Elgin's fives and numerology's five.

Six: Confusion surrounds the true nature of number six, because we are told that Gilead of Wommack "was no coward, and she was a true Six - her loyalty to her Family and her devotion to its members were her ruling qualities" (Elgin 2000: 351), yet the name Gilead is actually a number two. There are eight characters whose names make them sixes, but we learn very little about most of them. Chastity, Miranda, and Rosemary, all sixes, are the daughters of Jeremiah Thomas Traveller the 26th and Suzannah of Farson. Marycharlotte of Wommack is the wife of Jordon Sanderleigh Farson the 23rd, the head of Castle Farson (Elgin 2000: 69). Cecelia is a teacher in the Teaching Order established by Jewel of Wommack, but we are not even told what Cecelia's family affiliation is (Elgin 2000: 480). Sally of Lewis is the Castle Housekeeper of Brightwater (Elgin 2000: 164). Dorothy of Smith is the eldest daughter of Castle Smith, typically an important, responsible position, but in a 
time of crisis, she is described as hysterical, blubbering, and stubborn (Elgin 2000: 276-277), and Responsible remembers that as a child Dorothy was prone to pinching other children (Elgin 2000: 35). Diamond of Motley, married to Halbreth Nicholas Smith the 12th, head of Castle Motley, "was a placid woman, gone stout and not the least bothered by it [...]. She had eleven children and an unshakable serenity" (Elgin 2000: 79). She is further described as "a typical six, properly named" (p. 81) and as being uninhibited in her speech (p. 80). "She was a good woman, was Diamond, but she hadn't much grasp of logistics" (p. 85). Piecing together the scant evidence available, we can conclude that Elgin intends six to be associated with family, loyalty, and courage, but not necessarily with great intellect or problem-solving ability.

Elgin's sixes seem to have more in common with the family orientation of numerology's three than with its six. Taken together with the confusion about Gilead's number, there is little that one can say with confidence about what Elgin thought about the number six when she was naming her characters.

Seven: One major and three minor characters bear the number seven. Naomi of Wommack is a Teacher Candidate, newly arrived from an isolated rural area of the continent. Teacher Jewel approves of her confidence and her ability to look her superior in the eye, in spite of the difference in their rank (Elgin 2000: 477-478). Amanda of Farson, wife of Nathan Terfelix Clark the 17th and mother of Una, Zoë, and Sharon, displays no characteristics that would provide clues concerning the number seven (Elgin 2000: 32-42). Anne of Brightwater, first cousin of Responsible, is married to Stewart Crain McDaniels the 6th, the head of Castle McDaniels. She is mother to nine children, and Silverweb is her only daughter. Anne is forthright and direct in her speech. "Anne of Brightwater had a quick temper, but a heart that melted at blood heat, nearly" (Elgin 2000: 28). Silverweb of McDaniels becomes an important character as the story progresses, but when we first encounter her, she is fifteen years old and unmarried, unusual in Ozark society, where girls typically marry shortly after the onset of puberty. Responsible, reflects, "Silverweb. I added it up in my head - she was a seven. Withdrawn from the world... that went with not marrying... secrets and mystery... that fit the hooded eyes and the intricate figure of her braids. From what I could see, this one was properly named, and living up to it" (Elgin 2000: 23). Eventually, Silverweb becomes a mystic, and together with Troublesome, saves Responsible and the planet. The only problem with Elgin's characterization of Silverweb as exemplifying the properties of a seven is that those properties do not characterize the other women who bear that number. Silverweb's personality does reflect numerology's seven, which is associated with spirituality, mysticism, perfection, order, aloofness, and empathy (Nomenology 1999: 36). Perhaps Elgin simply concentrated on this major 
character and paid less attention to making the minor sevens reflect these qualities.

Eight: There are just three characters bearing the number eight. Teacher Cristabel is mentioned only briefly (Elgin 2000: 479). Flag of Airy is a servingmaid of Brightwater who was instructed to allow Vine of Motley to nurse her baby when Vine's baby was kidnapped. For the sacrifice of giving up nursing her baby for eight weeks, she was rewarded with the grant of a small parcel of land. Responsible of Brightwater is the main eight and the main character of the story. We learn little about the number eight per se, but we learn a lot about this Responsible and about Responsibles in general. There is a Responsible in every generation, and the most important aspect of Proper Naming is for the Grannys to discern who is a Responsible. Responsible is as much a title as a name. Unbeknownst to everyone other than the Grannys and Responsible herself, each Responsible is, in her lifetime, the meta-magician on Ozark, with power that exceeds even a Magician of Rank. She functions as the unacknowledged head of the planet, and her name literally defines her role. In the novels, not realizing the true role of the Responsible, the Magicians of Rank collectively use their power to bind Responsible of Brightwater in a pseudocoma, thereby unwittingly sending the planet into crisis by cutting off the conduit through which all magic flowed. With so much weight on the unique role of Responsible, it is difficult to discern the general characteristics of an eight, but all three eights seem to serve others and shoulder responsibility willingly, so that may be the closest we can come to a generalization.

Responsible does live up to numerology's association of eight with regeneration, stability, eternity, justice, equilibrium, balance, and tenacity (Nomenology 1999: 36). The balance and stability of her world depends entirely on her, and it is only through her tenacity that she persists in the face of adversity and resistance.

Nine: Una of Clark is the only nine in the story. She is the eldest daughter of Amanda of Farson, and she "had scandalized her parents by marrying a Traveller, and gone on to scandalize the Families nearby by loving him far beyond what was either decent or expected" (Elgin 2000: 33). Under the influence of her husband, Gabriel Laddercane Traveller the 34th, Una performs the magic that initially causes disruption on Ozark, including the kidnapping Vine of Motley's baby. We can infer that a nine may be weak-willed and easily duped, but with only one character to consider, it is impossible to know for certain.

Western numerology characterizes nines as being self-centred and egotistical, with lofty goals and high ambitions. Una of Clark is self-centred and egotistical, and she latches onto her husband's high ambitions. With only once character that illustrates nine, it was, perhaps easy for Elgin to achieve consistency with respect this number. 


\section{Evaluation of Elgin's system}

Nowhere does Elgin reveal the source of her numerology, but if Elgin had utilized a pre-existing numerological system, then one might expect her system to correspond more closely than it does with the kind of 'standard' Western numerology summarized above. However, a comparison of the scant information Elgin provides about the meaning of her numbers with the summary by the Nomenology Project demonstrates that such is not consistently the case. There is partial overlap between the two systems, but there are nearly as many contradictions as there are consistencies. Thus, it seems that Elgin did not seek to align her system closely with standard Western numerology, except insofar as she used the same letter-number equivalencies.

As an author and a linguist, Elgin typically paid close attention to details, particularly linguistic details, as evidenced by the fact that she invented an entire language, Láadan, for her Native tongue trilogy, and she was in the process of inventing another new language for a novel she was working on before her health made it impossible for her to continue writing. It is, therefore, surprising that after going to the trouble of incorporating a magical naming system and making it a central part of the plot of the Ozark trilogy, Elgin did not develop it fully or consistently. The example of the character Gilead being identified as a six when she is actually a two is the most glaring example of an error in Elgin's system, but there are inconsistencies throughout. The casual reader may be unlikely to notice or care whether Gilead is a two or a six and whether Elgin's brief descriptions of those numbers are consistent or inconsistent. However, for the onomastician, such details are important to the integrity of the story. "Careful readers have learned to scrutinize the onomastica in the fictions they read, for literary artists habitually exploit the significative power of names" (Robinson 1972: 131).

Elgin is not, of course, the only author of science fiction who has attempted a complex naming system, only to fail to have it realize its full promise. Walter E. Meyers summarizes the naming system Ursula K. Le Guin invents for The Dispossessed and notes the following problems:

I have read almost all the stories and novels of Ursula Le Guin, and her works are linguistically sound and inventive to a degree attained by very, very few writers in or out of science fiction. But in the case of The Dispossessed, she has erred badly. It is twice mentioned in the novel (for example, p. 39) that Annares contains 20 million people. But by the method she has carefully outlined, almost 12 million people on Annares do not have a unique name, or have no name at all. And when you have no name, you are dispossessed indeed.

And there is a second grave difficulty with the system, one that apparently did not occur to the author. Every two-syllable Pravic work which begins and ends with a consonant and has only one consonant combination is also someone's 
name. If English had the same system, someone somewhere would be named Hatrack, and Goofus, and Stupid, and Lizard, and Fumble, and on and on and on. Any society wherein I run the risk of being known to the world as Toenail is not my idea of a utopia.

But novels depicting a society with its own official system of onomastics are few and far between. The Dispossessed is noteworthy that it is one of them, even if its system does not work. (Meyers 1977: 117-188)

\section{Conclusion}

Elgin explains that she began writing the Ozark trilogy by accident when she was teaching a science fiction writing class. Making a point about the freedom of an author to digress from what is really possible, she asked her students to pick an animal.

They picked mules, and I went to the blackboard and wrote: "I should have known that something was wrong when the Mules started flying erratically." I did that to start a discussion about how to write the opening sentence of a novel. We discussed what a reader would know after reading just that one sentence on the blackboard. We talked about whether the sentence was as good a way to start a novel as writing a half-page of detailed description would be. We talked about what it means to write a novel in the first person, from the viewpoint of "I." We talked about the usefulness of "I should have known that something was wrong" as the opening to a narrative. And the more we talked, the more the idea of a novel to go with the sentence on the blackboard filled out in my mind. That's how it started. (Elgin 2001: n.p.)

Later in the same "FAQ" webpage, Elgin shared, "I was absolutely serious about the politics, the linguistics, and the theology; I wasn't serious about the numerology or the flying Mules" (2001: n.p.).

John Algeo makes an observation about authors of fantasy literature, and I would argue that his observation applies equally to authors of science fiction. He writes, "Fantasy writers are name-givers with no restrictions other than those they choose to observe to make the work coherent" (Algeo 2001: 252). From that perspective, the gaps and inconsistencies in Elgin's Proper Naming system might be overlooked if the novels otherwise capture the imagination of readers who are only interested in a good story. For the rest of us, though, no matter how much we may enjoy the story, we cannot ignore the fact that with a little more effort, Elgin's Proper Naming system might have reached the level of true artistry. 


\section{References}

Algeo, John. 2001. A fancy for the fantastic: Reflections on names in fantasy literature. Names 49(4), 248-252.

Brown, P. W. F. 1954. Names magic. Names 2(1), 21-27.

Elgin, Suzette Haden. 1980. The gentle art of verbal self-defense. New York: Dorset Press.

Elgin, Suzette Haden. 1981a. Twelve fair kingdoms. New York: Doubleday.

Elgin, Suzette Haden. 1981b. The grand jubilee. New York: Doubleday.

Elgin, Suzette Haden. 1981c. And then there'll be fireworks. New York: Doubleday.

Elgin, Suzette Haden. 1984. Native tongue. New York: Daw Books, Inc.

Elgin, Suzette Haden. 1987. The Judas rose. New York: Daw Books, Inc.

Elgin, Suzette Haden. 1993. Earth song. New York: Daw Books, Inc.

Elgin, Suzette Haden. 2000. The Ozark trilogy. Fayetteville: University of Arkansas Press.

Elgin, Suzette Haden. 2001. The Ozark trilogy FAQ.

(http://www.sfwa.org/members/elgin/OzarkTrilogy/oztrilfaq.html)

(Accessed 2014-12-23.)

Greenwood, Susan. 2009. The anthropology of magic. Oxford \& New York: Berg.

Le Guin, Ursula K. 1974. The dispossessed. New York: Harper \& Row.

Meyers, Walter E. 1977. The dispossessed and how they got to be that way: Ursula K. Le Guin's onomastics. Names 25(2), 115-118.

Nomenology Project. 1999. The hidden truth of your name: A complete guide to first names and what they say about the real you. New York: Ballantine Books.

OED online $=$ Oxford English dictionary online. (www.oed.com/) (Accessed 2018-01-28-29.)

Robinson, Fred C. 1972. Appropriate naming in English literature. Names 20(2), 131-137. 